\title{
MONITORING THE PULSE OF RENEWED SPANISH WATERFRONT CITIES THROUGH INSTASIGHTS
}

\author{
PABLO MARTI ${ }^{1}$, CLARA GARCÍA-MAYOR $^{2}$ \& LETICIA SERRANO-ESTRADA ${ }^{3}$ \\ Building Science and Urbanism Department, University of Alicante, Spain.
}

\begin{abstract}
This study provides an analytical approach to using collaborative heatmaps from Instasights to gain an insight on the impact of renewed waterfront urban areas in terms of their relevant role in the perceived functional dynamism and livability of the city. The proposed method enables the identification of perceived functional thematic areas - districts, as Kevin Lynch would refer to them in his work 'The Image of the City' - based on user-generated social media data, although the method adopted in this study diverges from that of Lynch, which is based on fieldwork. Instasights is used as a research tool because the demo app collects, analyzes and visualizes data from a vast amount of social media. Five waterfront Spanish cities—Madrid, Barcelona, Valencia, Bilbao and Zaragoza—have been selected as case studies to validate the method used. The main novelty of the study is the possibility of monitoring urban environments, even though they may be perceived as several thematic areas. The findings suggest that the proposed method is a valuable tool for gauging the pulse of waterfront areas through Instasight heatmaps. Moreover, differences in the way renewed public spaces are used and perceived, as well as overlapping functional areas are identified in the case study cities. The approach taken in this study provides a deeper understanding of the perception and complex dynamism related to the monitoring of the waterfront post-renewal phase, which enhances the study of urban renewal.

Keywords: collaborative maps, heatmaps, Instasights, LBSN, Perceived functional thematic area, social media, urban landscape, urban perception, Urban waterfronts, Voluntary Geographic Information.
\end{abstract}

\section{INTRODUCTION}

Urban renewal programs are critical for a city's strategic management, absorbing a significant share of public finances allocated to the city budget. One of the most important initiatives for improving urban tissues in coastal or riverside cities is focused on waterfront areas, where historically industrial activities were based until the economic restructuring that began in the early 1980s. Huge efforts were made to renew these obsolete areas of the city, and the image of most, if not all, renovated city areas has changed radically.

In the case of waterfront cities, renewal issues become a higher priority as water bodies have a strong influence, not only on the economic, natural and cultural heritage of the city, but also on the citizen's sense of belonging and the city's overall appeal. For this reason, methods for post-renewal monitoring of how the transformation of waterfront areas has impacted urban dynamics over time would greatly enhance the research in this field. Hence, this research finds its niche by designing a method for monitoring the post-renewed perception of urban waterfront areas. This requires the consideration of both physical, that is, morphological and functional configuration of spaces; and, non-physical aspects such as citizen preferences and perceptions. In both cases, the understanding of how individuals interact with and within, as well as how they perceive urban spaces is of great interest.

Traditionally, people's perception of urban space has been studied by interpreting collaborative mental maps. Indeed, these 'public images' project and overlap many personal

\footnotetext{
1 ORCID: https://orcid.org/0000-0002-6877-784X

2 ORCID: https://orcid.org/0000-0002-7714-3363

${ }^{3}$ ORCID: http://orcid.org/0000-0002-7466-1974
} 
impressions of a place [1]. Fortunately, nowadays these impressions are continuously being reflected and updated through readily available communication technology, i.e. social networks, facilitating access to citizen's perceptual information, which traditionally required exhaustive field work, such as interviews and site observations.

In particular, there is a body of literature suggesting that the complex relationships between people and 'the digital becoming of spaces and places' can be and should be [2] approached through social media data [3]. Moreover, these data include spatiotemporal physical and nonphysical traces that can potentially reflect post-renewal spatial outcomes and their social perception [4]. In fact, the perception of the urban environment is commonly approached by researchers from location based social networks (LBSNs) [5]. These include the following: Twitter [6] and/or Foursquare [7] via sentiment analysis [8]; and, geolocated photo-based social networks such as Flickr [9]-[12]; Panoramio [13] (no longer available since November 4, 2016) and Instagram [10], [14], [15]. Some of these studies suggest that spatial perception nuances can be richer using complementary data sources [16].

Given the stance of the outlined literature insofar as the applicability of social network data to gauge the non-physical aspects of urban spaces, this study adds to the research field by assessing the perceived functional dynamism of renewed waterfront areas. The term perceived dynamism implies several approaches to contemporary urban phenomena such as spatial planning, urban dynamics, sense of place and time-space rhythms. This term connects spatial context to people preferences and is thereby used to gauge the impact that place renewal-waterfront areas in this case-has on people's activities. Moreover, the dynamism of these waterfronts is detected by ascertaining whether the area accommodates a principal activity or several activities of a different nature, which complement each other.

The overall objective of this study is to provide an analytical approach to using the collaborative heatmaps from Instasights [17] as a means by which to understand how the renewal of waterfront urban areas plays a relevant role in the perceived dynamism and livability of the city. To validate the proposed method, it is subsequently applied to five Spanish cities selected as case study, namely, Madrid, Barcelona, Valencia, Bilbao and Zaragoza, with the aim of monitoring and cross-checking the issues that deal with the impact of urban waterfront renewal in terms of perceived dynamism.

The structure of the paper is as follows. First, a literature review concerned with waterfronts and urban renewal is presented; second, an interpretation of collaborative mapping for analyzing perceived dynamism is provided; third, the case study waterfront cities are interpreted; and finally, the results, discussion and conclusions are presented.

\subsection{Waterfronts and urban renewal}

Urban waterfronts are city boundaries, always complex from the spatial, social and diversity of uses perspective, and thereby requiring a multidimensional approach. Waterfronts, as narrow strips of land that extend along the natural boundaries created by geographical features, function as spatial connectors at different scales. They interact with and provide access to different city areas [12, p. 75], generating strategic opportunities for urban renewal that often have to balance needs that are in direct conflict with one another, for example, logistics zones with leisure activities. The special threshold condition of these places make them 'key sites in struggles over economic and cultural transformation in cities' [18, p. 101].

From a general perspective, the process of transforming these areas throughout history has been directly connected with global economic and technological changes in shipping and city-marketing strategies [12]. This is not a new approach to the process of city renovation. 
As explained by Dirk Shubert in Waterfront Revitalizations [12, p. 74], towards the end of the 20th century waterfront revitalization initiatives in northern European countries involved the first contests and master planning proposals with participatory decision-making initiatives for planning strategies. From 2000, these processes evolved integrating private and public partnerships, and these renewed areas became a new symbol of the city's image.

In Spain, the renovation undertaken in Barcelona in the 1980s [19], [20], where urban planning decisions took into account social, political and economic factors, would serve as a model for subsequent renewal initiatives for many Spanish municipalities.

By the end of the 1980s city waterfronts were central to the urban renewal discussion. These waterfronts tended to be dilapidated or incongruous areas within urban tissues that had traditionally served as a means of communication facilitating commerce, and at times riverfronts also presented a hydraulic problem requiring management. Dating back to 1988, academic and professional reflection on the new relationship between the city and its water boundaries emerged when the UR journal-Urbanism Laboratory, Barcelona School of Architecture-in its second issue dedicated to the Urban Project, highlighted the transformation of Barcelona's port waterfront that had been converted into the city's new public space [21].

Moreover, in the mid-1990s the Urbanism journal-published by Madrid Architects Association-launched a special issue on the port and river transformations of several Spanish cities that possessed a specific urban character. This issue included an influential article 'Urban Ports. Transformation of dock areas in urban contexts' [22], which revealed two important aspects. First, the scale of these interventions that was bigger and more complex than those carried out previously, blurred the boundaries between the urban tissue and river or maritime fringes. Second, people's perception of the role of waterfront areas changed because the renewed waterfront areas provided them with a physical connection to the other natural geographical features at a territorial scale [23].

In the first stage, urban waterfront renewal can be seen as a physical change, involving new uses and different intensity of land occupation as the '...outcome of the action of economic and social forces upon urban areas' [24]. Subsequently, the social element becomes increasingly relevant because, according to Sairinen and Kumpulainen, the social dimensions of urban waterfront planning and renewal refer to the different ways that the waterfront can be experienced and used to better understand their qualities for the community [25]. The success of waterfront renewal is linked to changing perceptions of local residents and investors through place-making and city re-branding initiatives [26],[27].

In recent decades, the reorientation of waterfront activities from brownfields to commercial, residential or recreational areas is the way in which many coastal and river cities face the challenge of 'seeking to redevelop their urban waterfronts in the interest of economic competitiveness, place promotion, and tourism' [28]. Accordingly, there is an increasing trend to put culture - a catalyst for further social, economic and cultural development - at the heart of urban transformation projects [29],[30]. The culturally-led approach in urban renewal programs involves constructing new facilities to accommodate cultural and sporting events that differentiate a city's character and identity [31],[32], thereby facilitating the promotion of tourism and securing inward investment, which boosts the local economy.

\subsection{Collaborative mapping as a method for analyzing functional perception}

Understanding the perception of the built environment involves far more than the physical configuration and the resulting sensorial stimuli, and therefore, is a challenging task. It also largely relies on the individual's cognitive functions such as habits, memory and motivations, 
that establish affective links between people and the urban realm [33]. Thus, the perceived image of one single space may vary significantly between each observer.

One of the most effective methods to understand how the urban realm is collectively perceived is through collaborative mental maps for visualizing the collective image onto which the input of various individuals is put together and visualized in a single map. The contemporary approach to collaborative mapping is hereafter considered as the body of research based on user-generated social media data. The data represent individual inputs that, when interpreted together, can provide insightful clues about the perceived image of the urban realm, as suggested by the research developed thus far. For instance, Dunkel [34], whose perceptual cartographies use pictures from Flickr users; Cranshaw et al. [35] uses data from Foursquare to identify clusters of activity-Livehoods, as the authors refer to these clusters-to generate cartographies showing areas of distinct nature in the city; Lee et al. [6] retrieve data from Foursquare, Twitter and Gowalla for characterizing the city's functional urban areas according to people's activities; and, Noulas et al. [36], propose a tessellation of the city into functional areas that correspond to the most popular Foursquare venues within them.

Notwithstanding the novelty of the above cited works, collaborative mental maps as a method to approach perception are not new. Kevin Lynch, in his seminal work 'The image of the city', [1] was the predecessor of this method with a series of 'public maps', such as 'The Boston that everyone knows' [1, p. 67], which consisted of a single graphic representation of the city of Boston that included information obtained from: (i) field reconnaissance of the area by a trained observer that would gather essential site-based observations-the physical space - and (ii) lengthy interviews of residents - the perceived space-to grasp individuals' perceived image of the city [1]. In an attempt to find common ground on the perceived elements of urban form, Lynch suggests that, overall, there are five types of elements that define the city image: paths, edges, nodes, landmarks and districts [1, p. 46].

This study focuses on the districts, which are medium-to-large, two-dimensional urban areas that perceptually evoke a sense of being 'inside of' [1]. These areas are recognizable for having a common and identifiable character, thus, defining thematic units of the city. According to Lynch, among the physical characteristics that determine districts are 'thematic continuities which may consist of an endless variety of components: texture, space, form, detail, symbol, building type, use, activity, inhabitants, degree of maintenance, topography' [1]. Specifically, Lynch's 'districts' will be referred to in this study as perceived functional thematic areas and their identifiable character is determined by their perceived use and predominant activity; and their spatial delimitation will be determined by using Instasights heatmaps. This tool visualizes large quantities of voluntary geographic information (VGI) data that are retrieved and analyzed from over 60 different social media sources [37]. Therefore, Instasights heatmaps reflect thousands of individual impressions about a city, just as Lynch's public maps did, becoming a promising source of 'public maps', updated on a daily basis [38], thus reflecting the current reality of the city.

Instasights heatmaps identify four types of urban activity—sightseeing, eating, shopping and nightlife - by color gradients, see Fig. 1, where the red represents the denser areas and yellow the less dense in terms of thematic activity. Some districts may have variable boundaries (Fig. 1), others a stronger core, around which a thematic gradient gradually fades, and others just stand alone [1].

The novelty of this work is the use of Instasights heatmaps to identify rapidly changing perceived functional thematic areas. Indeed, this research tool has not been extensively used in the urban studies field, at least insofar as the scarcity of references in the scientific 

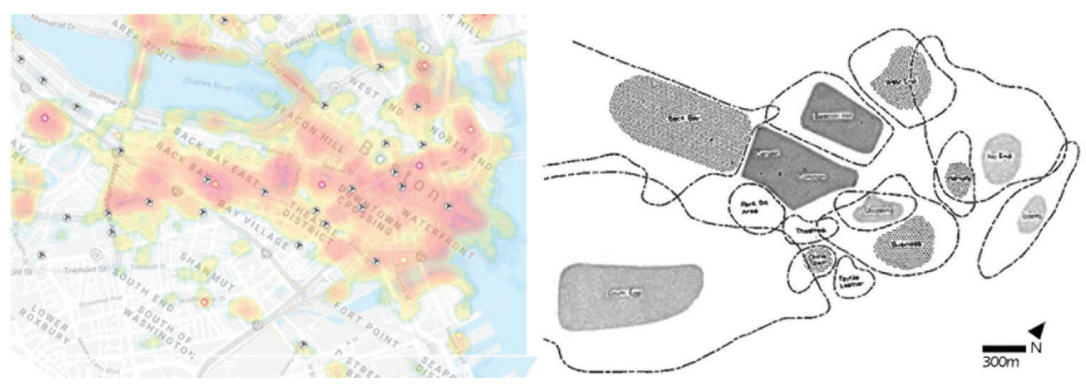

Figure 1: Instasights heatmap of Boston sightseeing 'best areas' (left) and the 'public image' of Lynch's Boston districts with variable boundaries $[1, \mathrm{p} .71]$.

literature would seem to indicate. Among these few references, Instasights heatmaps have been used to infer preferences and uses of the public space [39]; to identify preferred urban touristic areas [40] and, to pinpoint collective points of interest that may not be considered by other types of data [41].

\section{CASE STUDY SELECTION}

For this study, six representative waterfronts in five Spanish cities (Fig. 2) have been selected as case studies to compare the perceived dynamism through Instasights heatmaps in a variety of spatial renewal solutions, which have promoted new opportunities for the city at water boundaries. The waterfronts analyzed are two seafronts in the Mediterranean coast: Barcelona and Valencia; and, four riverfronts: Madrid, Valencia, Bilbao and Zaragoza.

The cities were selected for two main reasons. First, their waterfronts were brownfields, with, in some cases, industrial activities in decline, disconnecting urban waterfronts from the urban public space at their edges. Second, all of them have experienced a successful transformation of their maritime or fluvial areas in the last decades in terms of urban functional renewal, becoming highly dynamic hotspots for city economic activities and social life.

In all cases, these waterfront areas needed renewal and, after a preliminary Urban Plan orchestrated by various public institutions, in each case there were different event-led strategies - cultural or sporting - over the years, attracting new investment, revitalizing these renewed spaces and providing a spatial recognition linked to the activities for both locals and visitors. Table 1 summarizes some of the most relevant milestones in urban waterfront renewal for each case study.

\begin{tabular}{|c|c|c|c|c}
\hline & & City & Population (INE 2016) & Municipal Area (ha) \\
\hline $\mathbf{1}$ & Madrid & $3,166,000$ & 60630.5 \\
\hline $\mathbf{2}$ & Barcelona & $1,609,000$ & 9927.4 \\
\hline $\mathbf{3}$ & Valencia & 790,201 & 13967.7 \\
\hline $\mathbf{4}$ & Zaragoza & 661,108 & 97529.3 \\
\hline $\mathbf{5}$ & Bilbao & 345,122 & 4142.6 \\
\hline
\end{tabular}

Figure 2: Case study cities: population and municipal area. 
Table 1: Case study cities: Urban Waterfront Renewal Highlights.

\begin{tabular}{|c|c|c|c|c|c|c|}
\hline \multicolumn{7}{|c|}{ Urban Waterfront Renewal } \\
\hline \multicolumn{7}{|c|}{ Seafront } \\
\hline City & \multicolumn{2}{|c|}{$\begin{array}{l}\text { Public Administration- } \\
\text { LED }\end{array}$} & \multicolumn{2}{|c|}{ Sport Event-LED } & \multicolumn{2}{|c|}{$\begin{array}{l}\text { Cultural-LED or Research- } \\
\text { LED }\end{array}$} \\
\hline Barcelona & 1980’s & $\begin{array}{l}\text { General Urban- } \\
\text { Development } \\
\text { Plan }\end{array}$ & 1990’s & $\begin{array}{l}\text { Olimpic } \\
\text { Games } 1992\end{array}$ & 2000’s & $\begin{array}{l}\text { Universal Forum of } \\
\text { Cultures } 2004\end{array}$ \\
\hline \multirow[t]{2}{*}{ Valencia } & \multirow[t]{2}{*}{1988} & \multirow[t]{2}{*}{$\begin{array}{l}\text { General Urban- } \\
\text { Development } \\
\text { Plan }\end{array}$} & 2007 & $\begin{array}{l}\text { America's } \\
\text { Cup (sailing } \\
\text { event) }\end{array}$ & 2000’s & $\begin{array}{l}\text { The } 2000 \text { maritime } \\
\text { Valencia. Master } \\
\text { Plan. Urbanism } \\
\text { Department, Poly- } \\
\text { technic University } \\
\text { of Valencia }\end{array}$ \\
\hline & & & $\begin{array}{l}2008- \\
2013\end{array}$ & $\begin{array}{l}\text { Formula One } \\
\text { European } \\
\text { Grand Prix } \\
\end{array}$ & $\begin{array}{l}15 \text { th } \\
\text { century }\end{array}$ & $\begin{array}{l}\text { Historical city } \\
\text { bridges }\end{array}$ \\
\hline \multicolumn{7}{|c|}{ Riverfront } \\
\hline City & \multicolumn{2}{|c|}{$\begin{array}{l}\text { Public Administration- } \\
\text { LED }\end{array}$} & \multicolumn{2}{|c|}{ Sport Event-LED } & \multicolumn{2}{|c|}{$\begin{array}{c}\text { Cultural-LED or Research- } \\
\text { LED }\end{array}$} \\
\hline \multirow{3}{*}{ Valencia } & \multirow{3}{*}{1988} & \multirow{3}{*}{$\begin{array}{l}\text { “El Jardín del } \\
\text { Turia” Metro- } \\
\text { politan Park. } \\
\text { General Urban- } \\
\text { Development } \\
\text { City Plan }\end{array}$} & $\begin{array}{l}2008- \\
2013\end{array}$ & $\begin{array}{l}\text { Formula One } \\
\text { European } \\
\text { Grand Prix }\end{array}$ & 1987 & $\begin{array}{l}\text { Palau de la Música } \\
\text { (Concert Music } \\
\text { Hall) }\end{array}$ \\
\hline & & & 2014 & $\begin{array}{l}\text { Open } 500 \\
\text { tennis } \\
\text { competition. } \\
\text { Ágora Build- } \\
\text { ing }\end{array}$ & $\begin{array}{l}1998(1 \mathrm{st} \\
\text { pavillion })\end{array}$ & $\begin{array}{l}\text { City of Arts and } \\
\text { Sciences }\end{array}$ \\
\hline & & & $\begin{array}{l}\text { since } \\
2015\end{array}$ & $\begin{array}{l}\text { Urbans fes- } \\
\text { tival event: } \\
\text { skate, BMX, } \\
\text { parlour, } \\
\text { tricking, }\end{array}$ & 2004 & Cabecera Park Zoo \\
\hline \multirow{3}{*}{ Bilbao } & \multirow{3}{*}{1992} & \multirow{3}{*}{$\begin{array}{l}\text { Bilbao Ria } \\
2000 \text { Plan. } \\
\text { Public Com- } \\
\text { pany for Urban } \\
\text { Regeneration } \\
\text { of Metropolitan } \\
\text { Bilbao }\end{array}$} & yearly & $\begin{array}{l}\text { Bilbao } \\
\text { regatta of } \\
\text { trawlers }\end{array}$ & 1997 & $\begin{array}{l}\text { Guggenheim Mu- } \\
\text { seum Bilbao }\end{array}$ \\
\hline & & & 2013 & $\begin{array}{l}\text { Football } \\
\text { Stadium }\end{array}$ & $\begin{array}{l}2007- \\
2008\end{array}$ & $\begin{array}{l}\text { University of } \\
\text { Deusto new library. } \\
\text { Research center }\end{array}$ \\
\hline & & & $\begin{array}{l}2014- \\
2015- \\
2018\end{array}$ & $\begin{array}{l}\text { Red Bull } \\
\text { Cliff Diving } \\
\text { World Series }\end{array}$ & 2018 & $\begin{array}{l}\text { Bilbao Exhibition } \\
\text { Centre. Gala MTV } \\
\text { European Music } \\
\text { Award }\end{array}$ \\
\hline
\end{tabular}




\begin{tabular}{|c|c|c|c|c|c|c|}
\hline Zaragoza & 2001 & $\begin{array}{l}\text { The Ebro } \\
\text { Riverbanks } \\
\text { Plan }\end{array}$ & 2008 & $\begin{array}{l}\text { Expo } \\
\text { Zaragoza } \\
\text { Marathon } \\
\text { Whitewater } \\
\text { area - Ebro } \\
\text { Rivers } \\
\text { Swimming } \\
\text { Crossings } \\
\end{array}$ & 2008 & $\begin{array}{l}\text { International Ex- } \\
\text { hibition Zaragoza } \\
\text { "Water and sustain- } \\
\text { able development" } \\
\text { Zaragoza river } \\
\text { aquarium }\end{array}$ \\
\hline Madrid & $\begin{array}{l}2003- \\
2007\end{array}$ & $\begin{array}{l}\text { Madrid Rio } \\
\text { Master Plan }\end{array}$ & $\begin{array}{l}2009 \\
2011\end{array}$ & $\begin{array}{l}\text { Cycling } \\
\text { green belt } \\
\text { Urban beach } \\
\text { area } \\
\text { Skate } \\
\text { boarding and } \\
\text { roller skating } \\
\text { areas }\end{array}$ & $\begin{array}{l}15 \text { th } \\
\text { century } \\
\text { since } \\
2007 \\
2010- \\
2011\end{array}$ & $\begin{array}{l}\text { Historical city } \\
\text { bridges } \\
\text { Matadero Madrid } \\
\text { Multifunctional } \\
\text { Cultural Centre } \\
\text { Arganzuela monu- } \\
\text { mental bridge }\end{array}$ \\
\hline
\end{tabular}

\section{TOOLS AND METHOD}

\subsection{Instasights heatmaps as a tool}

As mentioned above, in order to identify the perceived functional thematic areas of the five case study cities, Instasights heatmaps [17] have been used as a main source of information. Instasights, a demo website of AVUXI TopPlace Heatmaps service, is a tool that gathers and analyzes 'billions of user-generated geotagged signals, regularly indexed across $60+$ public sources' [37]. This open access cartographic viewer-www.instasights.com-enables the visualization to be filtered into four main categories: sightseeing, eating, shopping, and nightlife, generating maps with a five-level color gradient (heatmaps) showing data density that reveals which are the most popular areas for each category.

Instasights web viewer presents three main limitations: (i) only one of the four categories can be displayed at once; (ii) the heatmap shape and spatial extension changes with the zoom view, thus, some urban areas that are covered by the heatmap when viewed at a larger scalezoomed out—, may not be covered if visualized at a smaller scale-zoomed in-; (iii) the edges of the five-level color gradient are blurred making it difficult to estimate which urban areas fall within the intense core gradient and which do not. These limitations can be easily dealt with by registering and signing in AVUXI TopPlace's webpage-https://www.avuxi. com/topplace-where access to broader map visualization options is granted for a trial-based limited time. One of the options available for AVUXI's registered users is the visualization of well delineated vector shapes of the five-level heatmap gradients per category. As opposed to the basic Instasights website heatmap viewer, the limits, size and spatial coverage of the vector-based concentric shapes remains the same, even if the user zooms the screen in or out.

\subsection{Method}

The overall method consists of the following three phases. Firstly, to identify perceived functional thematic areas, a similar methodological approach that the work of Perez-Sanchez, 
et al. [40] followed. A screen-shot of the AVUXI TopPlace's vector-shaped heatmaps with the vector-shaped visualization for each of the four categories-sightseeing, shopping, eating and nightlife-were produced for each case study city. The images were uploaded to a GIS program-QGis, Las Palmas version—and each level of the heatmap gradient vector shapes has been traced over the city's cartography. The resulting curvilinear shapes were colorcoded by category and were given different color shades to represent the heatmap's original gradient. The darkest shade indicates where the higher number of geolocated inputs registered for each category, revealing the location of most popular areas.

Secondly, the obtained cartographies are then analyzed and interpreted specifically considering the validity of the adopted tool in terms of the vector shapes delimitation, thematization and color gradation and, the perceived functional thematic areas obtained. This information is linked to the existence of specific cultural, commercial or public space landmarks in the identified waterfront areas.

Thirdly, a map is developed showing those urban areas where the intersection of three or four perceived thematic areas occur. These are analyzed and discussed in terms of the perceived dynamism of each case study city. The connection between specific cultural, commercial or public space landmarks in the renewed areas and the Instasights thematic areas is crosschecked.

\section{RESULTS}

Firstly, the obtained cartographies distinguish perceived functional thematic areas in the urban areas covered by Instasights heatmaps delimited shapes. Indeed, as these delimitations are the result of user-generated social media data, they can be considered to represent the collective image of the city, specifically where the sightseeing, shopping, eating and nightlife perceived 'districts' - as Lynch defines them-are located. In this regard, the proposed approach has provided information about social preferences and perception that can be complementary to that obtained from more traditional field work methods.

Moreover, despite the limitations of using Instasights heatmaps - undisclosed sources and algorithms-; there are some key characteristics that render this tool valuable for qualitative, and even quantitative research in grasping the perception of the city. To this end, Instasights has enabled suitable vector shapes to be delimited for distinguishing functional thematic areas that render possible the identification and size — quantitative — of the areas that are relevant for the perceptual image of the city-Lynch's perceived districts - and the least relevant areas.

When considering Instasights classification into the four thematic areas, there is a clear indication as to the predominant use, spatial extension and nodes of maximum data concentration within the waterfront areas studied. Therefore, the most active and popular places are visualized on the cartography. As observed in Figure 3 and Figure 4, the sightseeing category (Fig. 3, left), associated with leisure outdoor activities and spatially linked to the waterfront renewed areas, is the most representative in all studied cities, whereas, the other categories, namely, eating, shopping and nightlife, have a scattered distribution pattern in all cases.

The functional color gradient provides a complementary clue for analyzing the impact of a given space both, over the overall perceived thematic area and over other adjacent and/or concentric areas. As can be observed in Fig. 3-left, the color gradient of sightseeing areas indicated that the two most intense color nodes are areas spatially linked to the renewed waterfronts. These nuclei mostly correspond to cultural, patrimonial or natural elements, which are key characteristics for the identity of the city.

Furthermore, the heatmaps identify those spaces which have a significant influence on today's Livability of the city (Fig. 3 and Fig. 4). In Barcelona, the entire waterfront-from the 

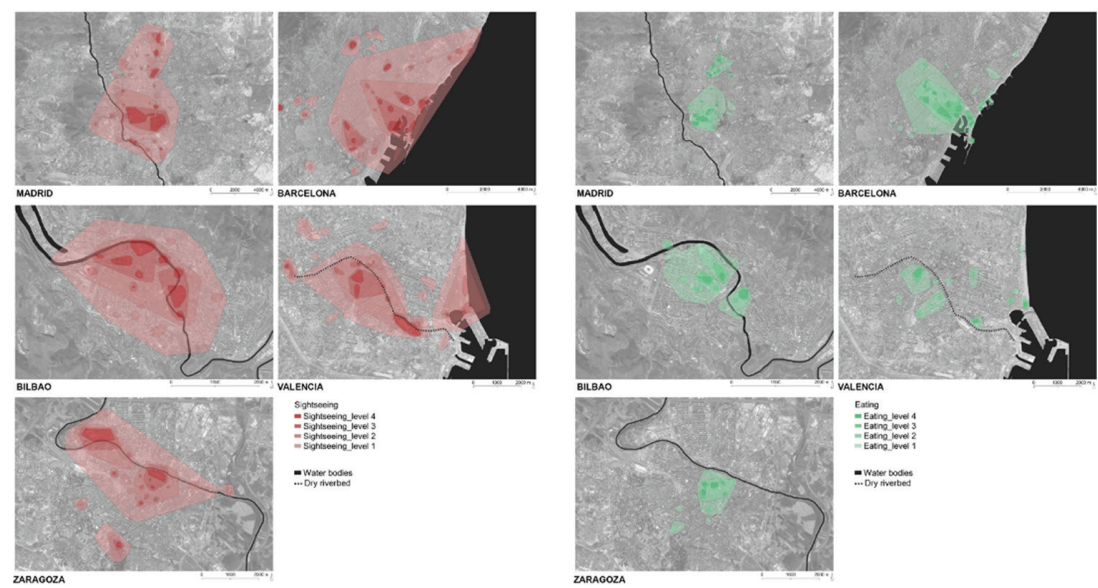

Figure 3: Left, gradient of perceived sightseeing areas; and right, gradient of perceived eating areas.

Source: Authors' own based on Instasights, AVUXI Top Places heatmaps.

southern Barceloneta neighborhood up to the northern Forum of Cultures-indicates high levels of interest from users. A similar situation is identified in Valencia, where both the old river bed of the Turia as well as the redeveloped port and the northern coastal front are clearly distinguishable from the rest of the city. In Madrid, a stretch of the Manzanares River has shown to be relevant in the collective image of the city as the heatmaps indicate a similar color gradient to other popular central urban spaces in the city. In Bilbao, in addition to the city's traditional spaces such as the historic center, the Bilbao estuary is where urban spaces of maximum intensity nodes are located. Also, the case of Zaragoza shows how the two focal points of attraction are located in the historic center and in the areas regenerated for the International Exhibition, both spaces are connected to the river Ebro.
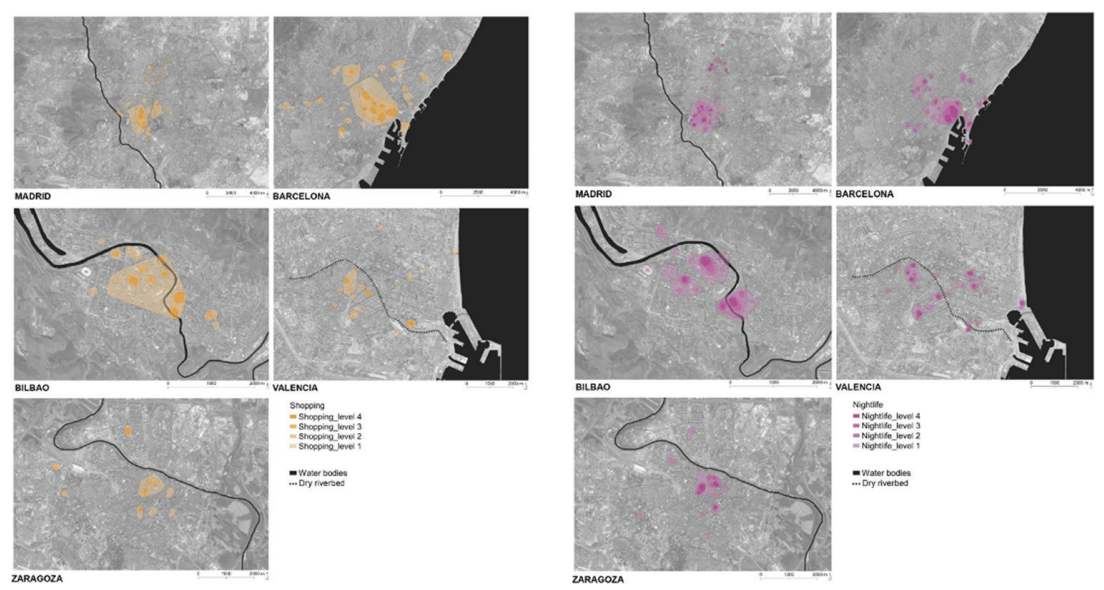

Figure 4: Left, gradient of perceived shopping areas; and, right, gradient of perceived nightlife areas.

Source: authors' own based on Instasights, AVUXI TopPlaces heatmaps. 

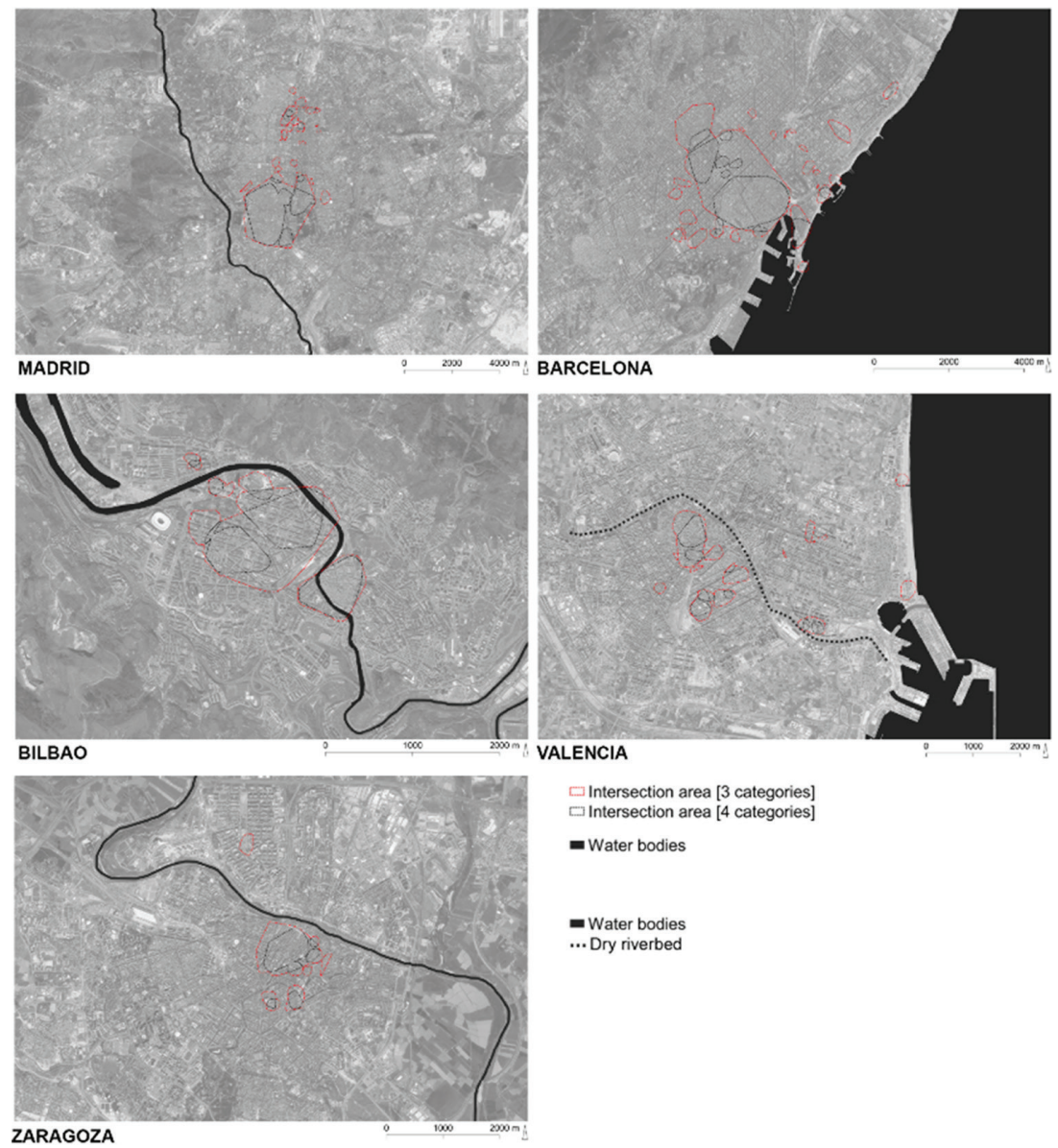

$\square$ Intersection area [3 categories]

$\square$ Intersection area [4 categories]

Water bodies

Water bodies

... Dry riverbed

Figure 5: Areas where three or four perceived functional thematic areas converge.

Source: Authors' own based on Instasights, AVUXI TopPlaces heatmaps.

Finally, the overlapping of perceived functional thematic areas permits the identification of areas where there is a presence of all Instasights categories (Fig. 5). This builds on the research of Lynch, who considered perceptual 'districts' as unique areas with a single recognizable character, but with variable edges (Fig. 2) as the extent of some areas may differ from person to person. The cartographies obtained by intersecting three or four Instasights categories (Fig. 5) show that a place could be cognitively understood as part of two or more functionally perceived thematic areas. This places an emphasis on the variation rather than exclusively the intensity levels of the type of the activity.

In this study, areas with higher perceived dynamism are those where three or four Instasights categories overlap. From the resulting cartography (Fig. 5), an interesting finding is that from the five case studies, only Bilbao has four overlapping categories linking both riverbank areas. Therefore, Bilbao is a successful example in terms of renewed urban dynamism, at least from the user perceptions. However, the other waterfront case studies are collectively perceived as sightseeing spaces more than other types of functional categories. 


\section{DISCUSSION AND CONCLUSIONS}

Instasights, as previously mentioned, presents a few limitations, namely, neither the exact data sources that feed Instasights heatmaps are publicly known nor the algorithm for pre-processing and interpreting data are specified by the developers. Despite this, several advantages for using Instasights as a research tool have been identified, in terms of the following instances: (i) identification of perceived functional thematic areas; (ii) monitoring of waterfront renewed areas and (iii) transferability to similar urban contexts.

In the first instance, Instasights has been useful as it allows the recognition and differentiation of perceived dynamism in a city. The fact that a public space, such as a plaza or a street, is perceived to be part of various thematic areas allows for a different perspective to be taken from that of Lynch, who suggested that 'districts' are unique in a recognizable character [43]; although he did affirm that some districts have boundaries that might be perceived as more or less defined depending on the person perceiving them. However, the overlapping of functions that exist in many of today's urban realities may result in the need to monitor the impact of waterfront renewal differently and that is one of the contributions of this research. For instance, a key landmark of the city such as a cathedral may be part of the sightseeing perceived thematic area by tourists, whereas if this landmark is located in a node with good concentration of commercial activity, then it may be perceived as part of the shopping thematic area by locals. The recognition of this perceptual overlap between thematic areas was made possible using Instasights.

In the second instance, the updating on a daily basis [38] of Instasights georeferenced information provides a dynamic tool for gauging the city pulse. Thus, the 'public maps', generated by the input of many social media users can be useful in the continuous monitoring of human activity patterns that indicate which urban spaces are perceived and experienced positively by citizens. Moreover, the perceived functional thematic areas through Instasights heatmaps may be temporarily altered over the course of an event or show more permanent variations after undergoing an urban renewal process, for example. Therefore, these collaborative urban images are capable of contributing to a deeper understanding of complex dynamism in urban contexts 'not simply mirror, they interpret an extraordinarily complex reality, and very often, quite different features of that reality' [42]. This is useful for grasping the perceived image of the city since, for example, a strong thematic area node that is surrounded by a fading color gradient may be perceived as part of the same urban area or 'district', because there is one element that 'radiates' to the adjacent areas just because of the sense of proximity to the node [1].

In the third instance, Instasights heatmaps categories: sightseeing, eating, shopping and nightlife, are well connected to predominant urban activities of, for example, touristic Mediterranean cities. This suggests the transferability of the method to other urban contexts, allowing the identification of the four main functional areas together with the overlapping system for detecting the places perceived as more dynamic.

To conclude, all the cities chosen as case studies clearly demonstrate social recognition of the renewed waterfronts as areas for leisure and open-air activities, mainly sightseeing. This is mainly due to the combination of sport and cultural event-led programming as shown in Table 1. Furthermore, the oldest waterfront renewals-Barcelona, Valencia and Bilbao- have the greatest degree of overlapping perceptual diversity. Of these three cities, Bilbao's renewal serves as model case, where the riverbanks are no longer a boundary but serve as physical and visual connectors between adjacent urban areas.

Finally, the validity of Instasights as a tool for monitoring the social perception of renewed urban waterfronts has been demonstrated by the proposed method of identifying and monitoring perceived functional thematic areas that is made possible by using collaborative heatmaps from Instasights. 


\section{REFERENCES}

[1] Lynch, K., The Image of the City, Massachusetts: MIT Press, 1960.

[2] Fekete, E., Urban renewal in the Hybrid City: Using data for development. In Handbook of Emerging 21st-Century Cities, eds. K. Bezdecny \& K. Archer, Edward Elgar Publishing, 2018, p. 464.

[3] Martí, P., Serrano-Estrada, L. \& Nolasco-Cirugeda, A., Social media data: Challenges, opportunities and limitations in urban studies. Computers, Environment and Urban Systems, 74, pp. 161-174, 2019.

[4] Zhou, X., Hristova, D., Noulas, A. \& Mascolo, C., Evaluating the Impact of the 2012 Olympic Games Policy on the Regeneration of East London Using Spatio-temporal Big Data. 2018.

[5] Martí, P., Serrano-Estrada, L. \& Nolasco-Cirugeda, A., Using locative social media and urban cartographies to identify and locate successful urban plazas. Cities, 64, pp. 66-78, 2017. https://doi.org/10.1016/j.cities.2017.02.007

[6] Lee, R., Wakamiya, S. \& Sumiya, K., Urban area characterization based on crowd behavioral lifelogs over Twitter. Personal and Ubiquitous Computing, 17(4), pp. 605-620, 2013. https://doi.org/10.1007/s00779-012-0510-9

[7] Cheng, Z., Caverlee, J., Lee, K. \& Sui, D.Z., Exploring millions of footprints in location sharing services. In Fifth International AAAI Conference on Weblogs and Social Media, Cholera, pp. 81-88, 2011.

[8] Aliandu, P., Sentiment analysis to determine accommodation, shopping and culinary location on foursquare in Kupang City. Procedia Computer Science, 72, pp. 300-305, 2015. https://doi.org/10.1016/j.procs.2015.12.144

[9] Dunkel, A., Spatial Pattern-Analysis of Flickr-Photo Distribution. Spatiotemporal tag cloud Fort Mason Center, San Francisco, 2012.

[10] Quercia, D., Aiello, L.M., Mclean, K. \& Schifanella, R., Smelly maps: The digital life of urban smellscapes. In International Conference on Web and Social Media (ICWSM), AAAI Press, pp. 327-336, 2015.

[11] Quercia, D., Schifanella, R. \& Aiello, L.M., The shortest path to happiness: recommending beautiful, quiet, and happy routes in the city. Proc. 25th ACM Conf. Hypertext Soc. media, pp. 116-125, 2014.

[12] Wartmann, F.M., Acheson, E. \& Purves, R.S., Describing and comparing landscapes using tags, texts, and free lists: An interdisciplinary approach. International Journal of Geographical Information Science, 32(8), pp. 1572-1592 2018. https://doi.org/10.108 0/13658816.2018.1445257

[13] Naaman, M., Geographic information from georeferenced social media data. SIGSPATIAL Special, 3(2), pp. 54-61, 2011. https://doi.org/10.1145/2047296.2047308

[14] López Baeza, J., Serrano Estrada, L. \& Nolasco-Cirugeda, A., Percepción y uso social de una transformación urbana a través del social media. Las setas gigantes de la calle San Francisco. I2 Innovación e Investigación en Arquitectura y Territorio, (5), 2016. https://doi.org/10.14198/i2.2016.5.03

[15] Hochman, N. \& Manovich, L., Zooming into an Instagram City: Reading the local through social media. First Monday, 18(7), 2013. https://doi.org/10.5210/fm.v18i7.4711

[16] Salas-Olmedo, M.H., Moya-Gómez, B., García-Palomares, J.C. \& Gutiérrez, J., Tourists' digital footprint in cities: Comparing big data sources. Tourism Management, 66, pp. 13-25, 2018. https://doi.org/10.1016/j.tourman.2017.11.001

[17] AVUXI LTD, InstaSights desktop viewer. [Online], available https://www.instasights.com/ 
[18] Desfor, G., Laidley, J., Stevens, Q. \& Schubert, D. (eds), Transforming Urban Waterfronts. Fixity and Flow, Taylor \& Francis, 2011.

[19] Borja, J., Luces y sombras del urbanismo de Barcelona, Barcelona: Editorial UOC, 2010.

[20] Montaner, J.M., La evolución del modelo de Barcelona (1979-2002). In Urbanismo en el siglo XXI: una visión crítica: Bilbao, Madrid, Valencia, Barcelona, ISBN 84-8301740-7, pp. 203-220, Barcelona: UPC, pp. 203-220, 2004.

[21] Laboratorio de Urbanismo (Barcelona), El poryecto Urbano II. UR Urban. Rev., (6), p. 50, 1988.

[22] Echavarri, J.P., Transformación de espacios portuarios en áreas urbanas. Urbanismo: revista oficial del Colegio de Arquitectos de Madrid, (27), pp. 6-17, 1996.

[23] Martí, P., García-Mayor, C. \& Melgarejo, A., Waterfront landscapes in Spanish cities: Regeneration and urban transformations. WIT Trans. Built Environ., 179, pp. 45-56, 2018.

[24] Couch, C., Urban Renewal: Theory and Practice, London: Macmillan Education LTD, 1990.

[25] Sairinen, R. \& Kumpulainen, S., Assessing social impacts in urban waterfront regeneration. Environmental Impact Assessment Review, 26(1), pp. 120-135, January 2006. https://doi.org/10.1016/j.eiar.2005.05.003

[26] Hoogendoorn, G. \& Gregory, J., Instagrammers, urban renewal and the johannesburg inner city. Urban Forum, 27(4), pp. 399-414, 2016. https://doi.org/10.1007/s12132-016-9287-7

[27] Raco, M., remaking place and securitising space: urban regeneration and the strategies, tactics and practices of policing in the UK. Urban Studies, 40(9), pp. 1869-1887, August 2003. https://doi.org/10.1080/0042098032000106645

[28] Xie, P.F. \& Gu, K., The changing urban morphology: Waterfront redevelopment and event tourism in New Zealand. Tourism Management Perspectives, 15, pp. 105-114, July 2015. https://doi.org/10.1016/j.tmp.2015.05.001

[29] Gunay, Z. \& Dokmeci, V., Culture-led regeneration of Istanbul waterfront: Golden horn cultural valley project. Cities, 29(4), pp. 213-222, August 2012. https://doi. org/10.1016/j.cities.2011.08.010

[30] Garcia-Mayor, C., Urban Tattoos for new Landscape narratives. Explorando el papel del arte urbano en el contexto de la ciudad contemporánea. I2 Innovación e Investig. en Arquit. y Territ., 5(1), 2017. https://doi.org/10.14198/i2.2017.5.04

[31] Evans, G., Measure for measure: Evaluating the evidence of culture's contribution to regeneration. Urban Studies, 42(5-6), pp. 959-983, May 2005. https://doi. org/10.1080/00420980500107102

[32] Iovino, G., Urban regeneration strategies in waterfront areas. An interpretative framework. Rivista J-Reading n. 1-2018: Journal of Research and Didactics in Geography, 1(7), pp. 61-75, 2018.

[33] Hall, P., Waterfronts: A New Urban Frontier, p. 24, 1991.

[34] Dunkel, A., Visualizing the perceived environment using crowdsourced photo geodata. Landscape and Urban Planning, 142, pp. 173-186, 2015. https://doi.org/10.1016/j.landurbplan.2015.02.022

[35] Cranshaw, J., Schwartz, R., Hong, J.I. \& Sadeh, N., The livehoods project: Utilizing social media to understand the dynamics of a city. 6th International AAAI Conference on Webblogs and Social Media. North America, 2012.

[36] Noulas, A., Mascolo, C. \& Frias-Martinez, E., Exploiting foursquare and cellular data to infer user activity in urban environments. 14th IEEE International Conference on Mobile Data Management. Milan, 2013. 
[37] AVUXI LTD, AVUXI Top Place heat maps, 2018. [Online]. available https://www. avuxi.com/topplace

[38] AVUXI LTD, AVUXI: Informed location-based booking decisions, 2018. [Online]. available http://www.avuxi.com/

[39] García-Mayor, C. \& Martí-Ciriquián, P., Frentes marítimo-fluviales en ciudades españolas: nuevos espacios urbanos. Bitácora Urbano Territorial, 28(3), pp. 71-79, 2018. https://doi.org/10.15446/bitacora.v28n3.72186

[40] Perez-Sanchez, V., Serrano-Estrada, L., Marti, P. \& Mora-Garcia, R.T., The what, where, and why of airbnb price determinants. Sustainability, 10(12), p. 4596, 2018. https://doi.org/10.3390/su10124596

[41] Padrón-Ávila, H. \& Hernández-Martín, R., Los puntos de interés turístico: Relevancia analítica, propuesta metodológica y caso de estudio. Pasos. Revista de Turismo y Patrimonio Cultural, 15(4), pp. 979-1000, 2017. https://doi.org/10.25145/j.pasos.2017.15.066

[42] AVUXI LTD, InstaSights, 2013, 2018. [Online]. available https://www.instasights.com (accessed 01 August 2018).

[43] Rodwin, L., Evans, H., Hollister, R., Lynch, K., Southworth, M. \& Susskind, L., Cities and City Planning, New York, NY: Springer Science+Business Media, LLC, 1981. 